\title{
Article \\ Online Store Locator: An Essential Resource for Retailers in the 21st Century
}

\author{
Gonzalo Wandosell ${ }^{1}$, María Concepción Parra-Meroño ${ }^{1}\left[\right.$ and Raul Baños ${ }^{2, *}$ (]) \\ 1 Department of Social Sciences, Law and Business, Catholic University of Murcia, 30107 Murcia, Spain; \\ gwandosell@ucam.edu (G.W.); mcparra@ucam.edu (M.C.P.-M.) \\ 2 Department of Engineering, University of Almería, 04120 Almería, Spain \\ * Correspondence: rbanos@ual.es
}

Received: 4 January 2019; Accepted: 12 February 2019; Published: 14 February 2019

\begin{abstract}
Most retailers use their websites and social media to increase their visibility, while potential customers get information about these retailers using the Internet on electronic devices. Many papers have previously studied online marketing strategies used by retailers, but little attention has been paid to determine how these companies provide information through the Internet about the location and characteristics of their stores. This paper aims to obtain evidence about the inclusion of interactive web maps on retailers' websites to provide information about the location of their stores. With this purpose, the store locator interactive tools of specialty retailers' websites included in the report "Global Powers of Retailing 2015" are studied in detail using different procedures, such as frequency analysis and word clouds. From the results obtained, it was concluded that most of these firms use interactive maps to provide information about their offline stores, but today some of them still use non-interactive (static) maps or text format to present this information. Moreover, some differences were observed among the search filters used in the store locator services, according to the retailer's specialty. These results provided insight into the important role of online store locator tools on retailers' websites.
\end{abstract}

Keywords: online store locator; information technology; retailing; geographic information systems

\section{Introduction}

Competition is strong in the retail market and likely to increase in the years to come. The retail sector is a huge part of the economic and social performance of any developed country. Economic globalization and the widespread use of information and communication technologies (ICT) are blurring spatial and temporal boundaries, which has prompted most medium-sized and large retail companies to adapt their structures and internal processes to the realities of this new era by expanding electronic, interactive, and direct marketing environments. With retailers selling their products through multiple distribution channels, product information management (Lin et al. 2010) has become an important part of the whole commerce solution implementation. Product information management helps retailers to provide product details and help customers better understand their products.

ICT play a critical role for the success of companies in a competitive environment, since these technologies help people to share knowledge through common platforms. In fact, digital technology has already started changing how consumers choose service providers. Furthermore, ICT help to establish social networks through their deployment via digital networks and to provide channels for communication and learning for improving products and services. Some recent studies have highlighted that traditional organizational systems are influenced by social networking tools (Soto-Acosta and Cegarra-Navarro 2016). This is an important issue, especially when considering that social networks can add value to the companies. The inclusion of these and other strategies are 
valuable resources for retail organizations, since they increase the amount of information shared with customers; facilitate data sorting, presentation, storage, and flow through the organization; and, finally, support the thoughts processes that inform effective decision-making (Yi and Jayasingam 2012).

Future growth for retail companies will depend on their ability to use creative methods and strategies to thrive under increasing competitive conditions. These actions have a direct impact in the Intellectual Capital of these firms, and therefore, in their competitiveness (Sydler et al. 2014). Among these strategies, marketing is a critical issue since it increases brand visibility and builds preference among customers. Several investigations have shown that marketing activities, such as advertising, are considered to be relational capital resources (Fernström 2005). In fact, relational capital includes marketing channels, relationships with customers, dealers, and suppliers, client loyalty, governmental and industrial networking, intermediaries or partners client relationships, etc. (Baxter and Matear 2004).

This paper studied the websites of specialty retailers around the world, in order to determine if they provided store locator that could be used by potential customers to find information about the location and facilities of the stores. Data provided in these websites, including the format (graphical or textual) and the degree of detail (information about the postal address, contact information, opening hours, facilities, etc.) was collected and analyzed using frequency analysis and word clouds.

\section{Marketing Strategies in the Retail Sector}

Some researchers have highlighted that the retail industry is dominated by fast-fashion and just-in-time production seeking to increase fashion trends (Pookulangara and Shephard 2013). Primary research interests in marketing applied to the retail sector are focused to analyze marketing strategies used by different types of retailers to promote goods and services. These include social media marketing, e-mail direct marketing, display advertising, and other emerging strategies with high potential, real impact in e-commerce and digital marketing (Tagg et al. 2012).

\subsection{Online and Physical Retailers Switch Roles}

Online retailers (e-retailers) constantly seek to enhance customer experience by updating their virtual stores with different strategies, such as mobile commerce, website personalization, videocasts, etc. (Tsai et al. 2013). General use of Internet and mobile devices is making a huge impact on the way consumers interact with brands, such that offline retailers are also stimulated to adopt some of the technologies commonly used by online retailers. But traditional retailers are not the only ones adopting digital technologies. E-retailers are also searching for physical stores, which is why it is possible to conclude that online and physical retailers are switching roles.

\subsection{Marketing on the Web}

Digital Marketing can be defined as the integration of strategies on the web looking for clear objectives using different tools, platforms, and social media (Saura et al. 2017). Digital marketing is closely related to web analytics, i.e., which is the process of collection, analysis, and reporting of website data for purposes of understanding the behavior of visitors and optimizing web usage. In fact, several studies have shown that web analytics can be used for digital marketing performance measurement (Järvinen and Karjaluoto 2015). The importance of web analytics in the retail sector comes from the fact that the former is widely used by popular websites to provide useful data for client companies (Saura et al. 2017). An open question here is whether geolocation could improve the results of the web analytics. Previous investigations have shown that e-business and external web services contribute positively to firm performance (Meroño-Cerdán and Soto-Acosta 2007; Palacios-Marqués et al. 2015; Soto-Acosta et al. 2016). Medium-sized and large retailers have adapted their websites to create efficient communication channels with clients. Two clear examples are e-commerce and social media (Saboo et al. 2016). On the one hand, these websites often show goods and services, which can be easily bought via e-commerce (Hackl et al. 2014). On the other hand, retailers aim to increase brand 
awareness and sales by enhancing their corporate image through social media. Some studies have shown that firms face internal and external pressures to increase their digital presence on websites and social media platforms (Tiago and Veríssimo 2014). This is especially important today, since one of the biggest future challenges for marketing, and, consequently, for retailing, are young consumers (millennials and generation $\mathrm{Z}$ ), since they seem to behave differently as consumers and are more focused on innovation (Priporas et al. 2017).

\subsection{Mobile Marketing}

The increase in the number of users of mobile devices around the world has promoted that the exchange of information based on location has become a trend on social networks (Kim 2016). With millions of people connected to the Internet using electronic devices, the interest in mobile marketing in the retail sector has increased remarkably. In fact, mobile marketing and its features can potentially increase a firm's performance (Ström et al. 2014), which is why retailers have devoted important resources to adapt their traditional digital marketing strategies to the specific characteristics of mobile devices. For example, large firms have designed mobile apps to provide specific services to the potential customers. Therefore, mobile marketing (Berman 2016) has become an important component of a firm's overall promotional strategy (Shankar 2016). Some studies have analyzed retailer mobile marketing strategies to identify customer-related and organizational challenges (Shankar et al. 2010).

\section{Geomarketing and Geographic Information Systems}

Location-based services (LBS) are services offered through mobile devices, according to the geographical location of its users. In recent years, the amount of geospatial data has grown rapidly, such that data from geosocial networks have become a comprehensively used basis for geospatial analysis in several application areas (Kounadi et al. 2018). Strategies considering geographical data have become powerful methods that enhance traditional marketing strategies. This issue is of great importance for potential customers, since it is well-known that distance (and time) is an important variable that determines whether a customer goes to a certain store to buy. Furthermore, large specialty retailers, which have thousands of stores around the world, can serve many customers daily. Since many real applications use geographic data, in recent years, location-based social network systems (LBSNS) have developed rapidly (Zhao et al. 2014). Several investigations have showed that advances in localization techniques enhance social networking services, allowing users to share their locations and location-related contents, such as photographs or activities (Bao et al. 2015; Palos-Sanchez et al. 2018).

\subsection{Geomarketing}

Geomarketing strategies play an important role in the definition of the retail sector (Cliquet 2006) and have become essential for those businesses interested in considering the spatial variable for decision support, such that it is possible to identify the points where a company will have higher benefits. Geomarketing has meaningful potential for developing marketing strategies to make business decisions based on spatial variables. This discipline is based on a set of techniques that analyze the socio-economic and demographic characteristics from a geographical viewpoint through spatial market segmentation (Chacón-García 2017). With this purpose, companies are increasing their efforts to optimize decisions related to the location of their facilities (Roig-Tierno et al. 2013), since retailers' expansion is faced with the challenge of assessing the impact of a store network extension on the performance of their existing stores (De Beule et al. 2015). These decisions often assume the probability that a customer patronizes a facility is inversely proportional to the distance between the customer and the facility (Fernández et al. 2017), among other key factors. Furthermore, geomarketing strategies are also used by media and advertising agencies to focus customer promotion campaigns on specific geographical areas where their target groups are located.

The main potential of geomarketing comes from the fact that it facilitates reaching local customers, Internet customers, mobile device users, and social media users. The companies can 
apply geomarketing strategies to identify customers that could be interested in a certain product, as well as those within half an hour's drive for the purposes of sending leaflets and flyers (Gijsbrechts et al. 2003). Furthermore, geomarketing is a useful tool to attract Internet customers, mobile device users, and social media users. Social media platforms are channels to send special offers to their users, according to their location. The advantages provided by geomarketing are specially interesting for retailers. For example, retailers can use the IP address of online shoppers or the stores they are searching to determine their location and to display the web pages in the language of the user or to send discounts or personal promotions to mobile phone users, according to the physical location at a specific moment. But in addition to the physical location of the customers, the information collected from store locator tools can be exploited to get information about which stores are of more interest to these customers.

Despite the aim of geomarketing strategies in identifying key opportunities for market strategy, planning locations of the stores, dividing sales regions to improve logistic organization, etc., applying geomarketing strategies is not a trivial issue. Thus, customer data collected from club cards, subscriptions, online transactions, mobile devices, and mail responses, etc. is stored in company databases. Afterwards, this data is applied to digital maps to be later analyzed by experts applying advanced analytical tools, according to specific business goals, such as identifying the location of customers for a new promotion.

\subsection{Geographic Information Systems (GIS)}

Geomarketing techniques are often supported by geographic information systems (GIS), which are powerful software tools that process geographical information considered of interest for decision-making processes in different areas of the organization. GIS software is of strategic importance for enterprises because it allows them to capture and analyze geospatial data, as well as including procedures that help to understand what occurs in geographic space. In Western countries, use of GIS in business, with applications in marketing, retail, restaurants, insurance, telecommunication, real estate, transport, etc. is increasing. In particular, the use of GIS in the retail sector allows retailers to obtain information about resources, suppliers, dealers, sellers, and customers, taking into account the geographical variable (Cliquet 2006), which is why GIS has become an interesting tool for marketing activities (Hess et al. 2004), including its use as an e-commerce tool with benefits for both the system's use and that of the service provider. To implement geomarketing strategies in practice, internal data, external data, and maps are integrated in GIS. Most GIS include tools for automatically determining the location of one or several facilities, according to the location of demand points, location of own facilities, and location of competitor facilities, which are useful to determine the location of facilities to ensure proper coverage of goods to serve customers in a geographical area (ELSamen and Hiyasat 2017). In fact, medium and large firms use database marketing that can optimize the value of their data using geomarketing strategies, since the customer address or zip code can be linked to a GIS. Some authors have analyzed the three classic location theories: central place theory, spatial interaction theory, and the principle of minimum differentiation in the retail sector. Reigadinha et al. (2017) have used a GIS to analyze these theories in a geographical area and concluded that decisions related to store location are related to the population density, since the larger the population density the smaller the store's distance from the center, and the larger the center the larger the market area and the store density.

\subsection{Web GIS}

In addition to the use of GIS software for geomarketing studies, organizations are increasingly using interfaces with citizens through web GIS open-access platforms (Zavala-Romero et al. 2014), to assist in the analysis and visualization of data. Web GIS are web mapping services, i.e., GIS embedded in websites that allow the Internet user to interact with maps, for example, to get information about the geographical location of the stores. Several authors have analyzed the use of web GIS in different 
applications. For instance, Yang et al. (2015) presented a method for evaluating potential sites for proposed hotel properties by using an automated web GIS application that included algorithms to predict business success indicators associated with hotel location selection. Recently, Albuquerque et al. (2018) have shown that GIS are powerful tools for the development of a sustainable tourism marketing strategy.

A web GIS is managed using a server (web application server), while clients use web browsers on desktop or mobile devices. Web GIS integrate GIS and Internet technologies to provide ubiquitous access to the distributed information, multi-user activity, data transparency, platform independence, and better visualization. Location searches based on web GIS operate in conjunction with online map services, such as Google Maps. The rise of web-based GIS resources has expanded the scale and scope of spatial information. The interest in web GIS has been reinforced by the development of new web services, cloud computing platforms, and mobile applications (Baños et al. 2016). The main advantage of web GIS is that it extends the typical GIS tools (spatial analysis, network analysis, etc.) so that it allows non-GIS professionals to conveniently process geographical data and to make decisions. Web GIS provides the end user with comprehensive and synthetic, both spatial and temporal, environmental information through a remotely customizable, user-friendly graphical interface without the need for a traditional desktop GIS application.

\section{Materials and Methods}

Several investigations have analyzed business models, s-commerce, adoption strategy, social process network analysis, firm performance, and website design, with the latter the most studied topic (Busalim and CheHussin 2016). Other authors have studied the use of web-mapping systems for decision support in different sectors and applications, including retailing (Roig-Tierno et al. 2013). According to Parise et al. (2016), retailers are starting to roll out location-based applications and services to deliver customized content to shoppers in the store or branch. An example is the inclusion of store locator tools in companies' websites that allow website visitors to find locations of stores within the proximity of a postal code or a given postal address.

Unfortunately, little attention has been paid in the literature to the use of web store locator. To cover this gap, this paper was devoted to rigorously justifying their importance in the field of digital marketing. The websites of 63 large specialty retailers around the world were analyzed in detail to obtain empirical evidence about the use of store locator services and interactive web maps (web GIS) in the retail sector. We noticed that social networks, such as Pinterest, Facebook, or Twitter were not objects of study in this investigation since they do not allow users to manage large databases but are used to provide insights about the brand, products, promotions, etc. However, customized websites are easily connected with searchable databases that allow data retrieval about store locators.

\subsection{Web Store Locator: A Powerful Tool for Businesses}

The popularization in the use of web store locators (mainly those using web GIS) is being facilitated by the possibility of visiting firms' websites from any device connected to the Internet, including mobile devices (smartphones, tablets, etc.). Recent studies have shown there is an increasing interest in downloading and using mobile location-based services retail apps (Kang et al. 2015). Location tracking is a personalized advertising and marketing practice that analyzes how store locator pages using interactive maps allow potential customers to find the store nearest to their location. Store locators are particularly important for those customers moving to a new place where they need to buy products found at specialty merchandise retailers.

On the other hand, it is worthy of mention that the potential of web GIS is not only limited to supplying geographical information to the users but also becomes an interesting tool to acquire knowledge from the clients. Previous studies have remarked that a trust-oriented interface design in a web GIS facilitates the development of e-commerce systems (Skarlatidou et al. 2013). 
Despite the great potentiality of web GIS in the retail sector, little attention has been paid in the literature to the analysis of strategies used by these firms to provide information through the Internet about the location and characteristics of their stores. In response to this lack in the literature, the websites of many specialty retailers around the world were analyzed to obtain empirical evidence about the use of store location tools.

\subsection{Analysis of Store Locator Tools in Retail Websites}

A criterion to classify retail stores is the breadth of products offered (Pride et al. 2014), which aims to classify retailers into two types: general merchandise retailers, which offer a large variety of product lines stocked in considerable depth; and specialty retailers, which offer substantial assortments in a few product lines. Given that physical retail is still the dominant operational format around the world, this study aimed to highlight the growing importance that firms give to the use of interactive maps to provide information about the location and characteristics of their stores. With this aim, this paper analyzed the strategies used by a set of large specialty retailers to present information on their websites about the geographical location of their stores and the services they provide, including the analysis of their use of web GIS.

We have considered the data provided by the report "Global Powers of Retailing 2015", produced by Deloitte Touche Tohmatsu Limited (Deloitte Touche Tohmatsu Limited (DTTL) 2015) with STORES media. The survey elaborated by one DTTL, one of the global audit firms (Fung et al. 2017), included information about the 250 largest retailers (63 of which are specialty retailers) around the world based on publicly available data for fiscal year 2013, and analyzed their performance across geographies and product sectors. It is important to remark that changes in the overall ranking from year to year are generally driven by increases or decreases in companies' retail revenue, although a weaker (stronger) currency vis-à-vis the US dollar in 2015 meant that companies reporting in that currency may rank lower (higher) in the next year, all other things being equal (Deloitte Touche Tohmatsu Limited (DTTL) 2015). The reason to analyze the 63 specialty retailers from the 250 included in the report is to determine whether there are differences in the search strategies and retrieval data between companies from different sectors. The report "Global Powers of Retailing", which is referenced in some previous scientific papers (Chambolle and Villas-Boas 2015; Head et al. 2014), classified specialty retailers into several categories, according to the activity included in Deloitte Touche Tohmatsu Limited (DTTL) (2015), i.e., apparel-foot (22 firms), drug/pharmacy (14 firms), electronics (15 firms), and home improvement (12 firms).

Different website analysis strategies have been used in the past (Fernández-Cavia et al. 2014). For example, Ríos-Martín et al. (2017) proposed an index that considers accessibility, navigability and usability, and speed and quality of content. However, some of these factors depend of a large variety of circumstances. For example, it is well-known that the loading speed of your website is often slower as the distance between your website's visitor location and server's location increases. Given that our study included 63 retailers' websites, most of them located in different countries or continents, the navigability and speed depended on the (unknown) location of the servers. Therefore, our study was focused on study of the search options, as well as the format and content of the results retrieved from store locators. Menus and search tools on the website of these companies were analyzed to determine how these specialty retailers provide information about the location of their stores. In those cases, in which this information was not easily found in the websites, Google's search tool was used to find this information (the searches included the company name and the words "find stores", "store finder", "store locator", "shop finder", "shop locator", "stores", etc.). Google translator was used to facilitate the search process of those websites in which no English version was available. The results retrieved from this double search (companies' websites and Google search) were analyzed to determine whether these companies provide web GIS in their websites to facilitate the customers to find their stores, and if they do, which were the characteristics of the information provided. The information was classified according to two criteria: 
- Format: This criterion refers to the way in which the company shows information about their stores. Three formats were detected: List/table, a static map that often redirects to a list/table, and web GIS.

- Information provided: This criterion refers to the information provided about their stores. The following information was detected in the same URL of websites including list/tables, static maps, and web GIS or a direct link to them: postal address, contact information (like telephone/fax/email), store hours, store services/facilities, and directions to stores.

Since Deloitte Touche Tohmatsu Limited (DTTL) (2015) includes many global companies, they usually have stores in various countries, and therefore, different websites in each one. To analyze the use of web GIS in these cases, the companies' websites of the country in which the matrix is located were selected. When companies had several brands in the same dominant operational format, they were analyzed in decreasing order of appearance, aiming to find geographical information about their stores. Information about postal address, contact information, store hours, store services/facilities, and route planner to get directions was also considered when it was included directly in the web GIS, or textually in the same webpage, or in a direct link. The results retrieved were obtained by performing a basic search using the store locator tools. In some cases, the search engine directly returned information about the nearest establishment, according to our location. In other cases, a list or map with the stores was provided, and one of them was randomly selected.

Quantitative and qualitative methods were considered to analyze the information collected from websites about store locator tools in order to show the similarities and differences in the information provided by companies of different types of specialty retailers. With this aim, in addition to some basic statistics, word clouds (Tessem et al. 2015) were used to analyze qualitative data about both the search tools included in companies' websites and the results retrieved from these searches. The word cloud is a visualization technique that provides the reader a bird's eye view of a text or manuscript. Using word clouds is a good way to get knowledge into the hands of visual learners since it allows visualization of a set of documents in a succinct way by representing the word frequency of that text, such that the more times a word appears in the text, the bigger the size this word is in the word cloud. In this paper, we used an online word cloud generator capable of constructing the word cloud by uploading a given file containing the text to analyze.

\section{Results and Discussion}

Table 1 summarizes the data collected from the search performed through the websites of the companies having apparel-foot, drug/pharmacy, electronics, and home improvement as dominant operational format. According to the results obtained, 61 out of 63 companies (96.8\%) used web GIS to provide information about their stores, whereas only two companies $(3.2 \%)$ used static maps or employed a table or list to display this information. Most of the 61 companies that included interactive maps in their website used Google Maps mapping service (90\%), while Microsoft HERE or ZENRIN were the other alternatives. Regarding the specific information provided, most locator tools provided useful information about each location. In fact, almost all the firms included the postal address (98.0\%) and contact information (94.4\%) on their websites, while opening hours were also provided by most firms (84.9\%). Nevertheless, the percentage of websites that included information about the services offered by the stores was $48.8 \%$. Finally, it was observed that only $40.5 \%$ of the websites included information about the best way to reach these locations (automatic route planner to get directions or textual information about the routes to arrive using public or private transport). 
Table 1. Summary of information provided by general merchandise retailers, according to the store format.

\begin{tabular}{cccccccc}
\hline & Firms & Web GIS & $\begin{array}{c}\text { Postal } \\
\text { Address }\end{array}$ & $\begin{array}{c}\text { Contact } \\
\text { Info }\end{array}$ & $\begin{array}{c}\text { Store } \\
\text { Hours }\end{array}$ & $\begin{array}{c}\text { Store } \\
\text { Services }\end{array}$ & $\begin{array}{c}\text { Route } \\
\text { Planner }\end{array}$ \\
\hline Apparel-foot & 22 & $100.0 \%$ & $100.0 \%$ & $100.0 \%$ & $77.3 \%$ & $27.3 \%$ & $36.4 \%$ \\
Drug pharmacy & 14 & $85.7 \%$ & $100.0 \%$ & $92.9 \%$ & $85.7 \%$ & $64.3 \%$ & $28.6 \%$ \\
Electronics & 15 & $100.0 \%$ & $91.7 \%$ & $83.3 \%$ & $83.3 \%$ & $58.3 \%$ & $50.0 \%$ \\
Home improvement & 12 & $100.0 \%$ & $100.0 \%$ & $100.0 \%$ & $100.0 \%$ & $58.3 \%$ & $50.0 \%$ \\
Mean & & $96.8 \%$ & $98.0 \%$ & $94.4 \%$ & $84.9 \%$ & $48,8 \%$ & $40.5 \%$ \\
\hline
\end{tabular}

As it is seen, apparel-foot and home improvement firms often provided information about the location of their stores using web GIS and basic information about the address and contact information (email or telephone number). On the other hand, electronics and home improvement stores were those that showed more interest in providing information about how to arrive to the stores. Finally, drug/pharmacy firms are, on average, more interested on providing information about the facilities offered in the stores than the other store formats.

Figure 1 shows the word clouds in websites of the four types of specialty retailers analyzed. As it can be seen, main words ("store", "search", find", etc.) seem to be commonly used independently of the type of specialty. Nevertheless, some differences are observed with other terms. Drug/pharmacy stores and electronic stores often included some additional search filters of products in their store locator websites, while it was not so common in apparel-foot and home improvement specialty retailers. For example, some drug/pharmacy stores included search filters, such as "pharmacy/store open 24 Hours", "drive-thru pharmacy", or "healthcare clinic". Some common search filters in electronic retailers were "computers", "TV image", "photo and video", and "games", among others.

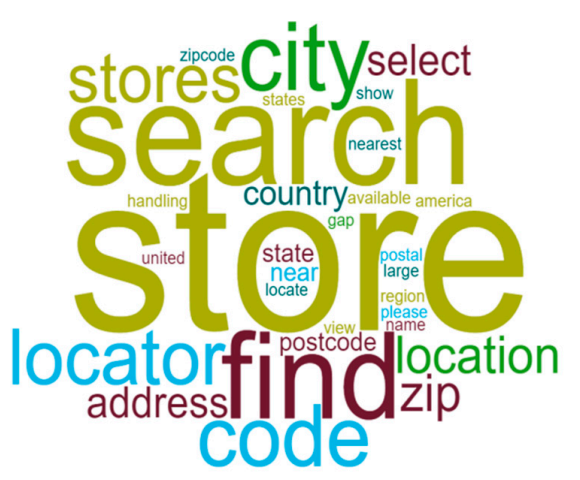

(a) Apparel-foot

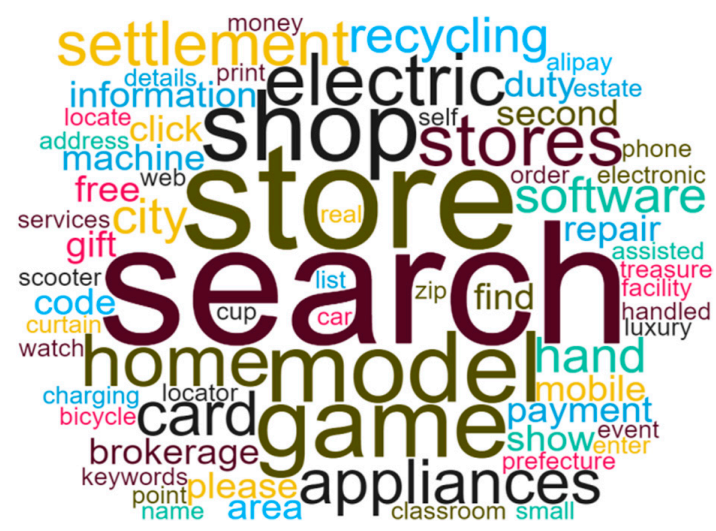

(c) Electronics

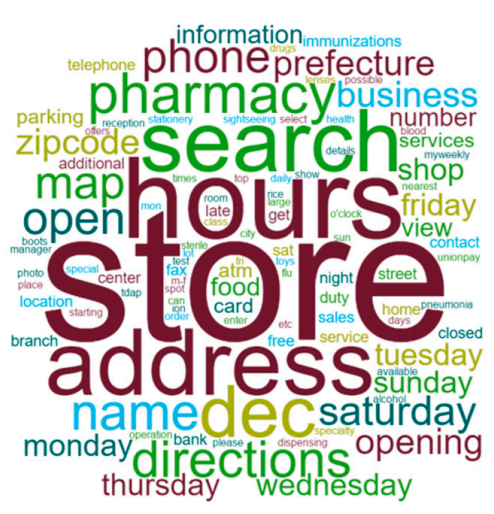

(b) Drug/pharmacy

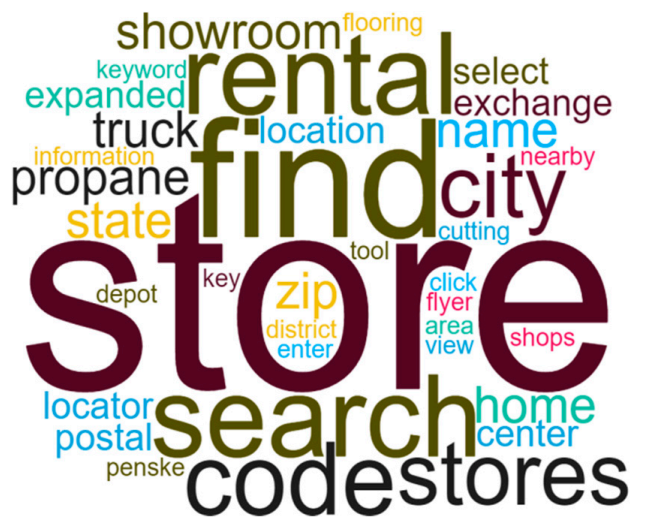

(d) Home improvement

Figure 1. Word clouds on websites of specialty retailers (search tools). 
On the other hand, Figure 2 shows the word clouds of the results obtained after the user performed a search in the store locator websites. Here again, words retrieved from companies' websites of the same retail specialty were grouped in the same text file for its analysis. As it can be seen, the main words were now related to the basic information about the stores ("store", "address", hours", "phone", "telephone", "zip code", etc.). Drug/pharmacy stores and electronic stores also included some information about their products in their results. For example, some concepts retrieved from electronic retailers' websites were "appliances", "game", "card", and "software", among others.

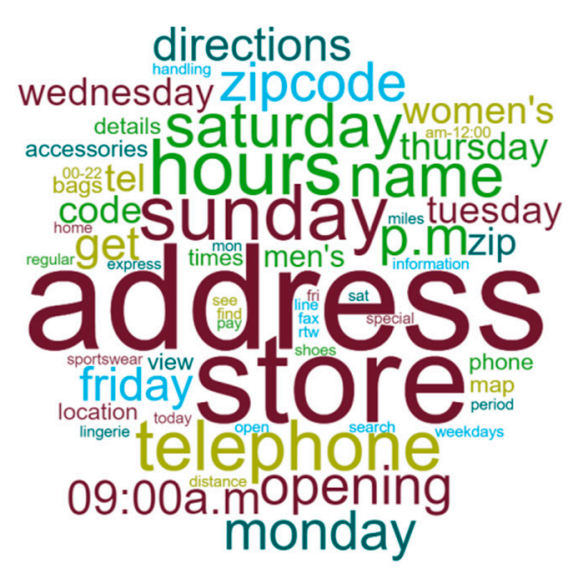

(a) Apparel-foot

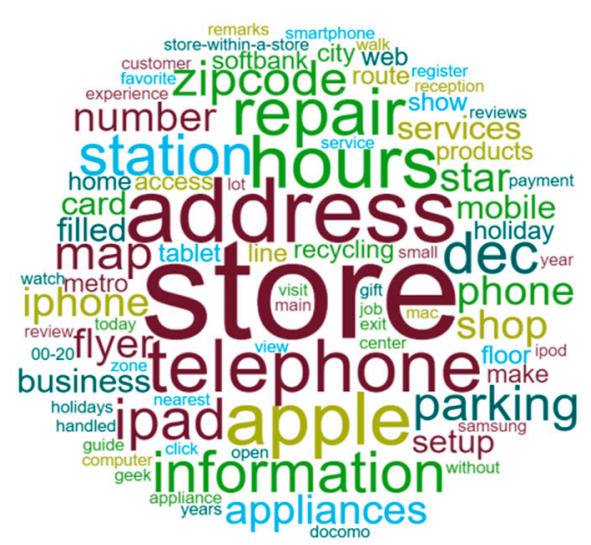

(c) Electronics

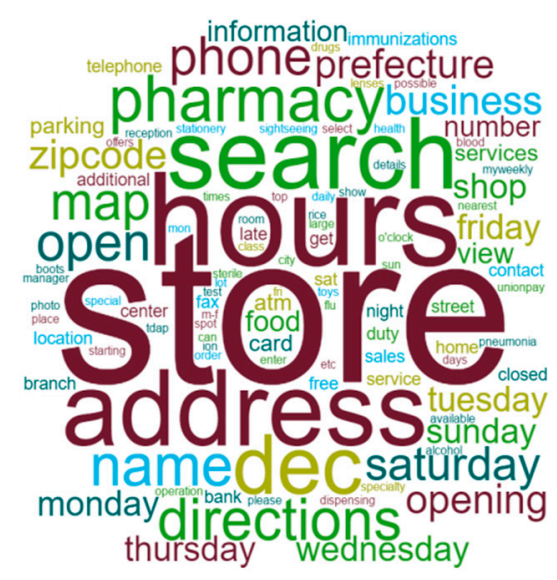

(b) Drug/pharmacy

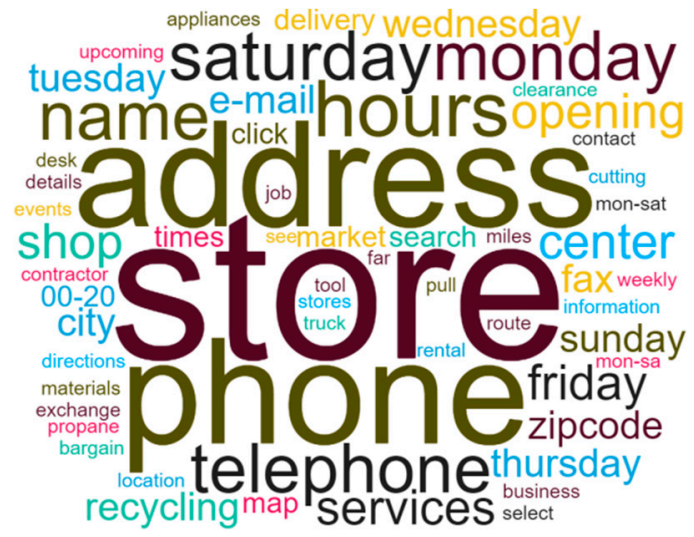

(d) Home improvement

Figure 2. Word clouds on websites of specialty retailers (results retrieved from a search).

In summary, it was concluded that most large specialty retail firms included store locator tools on their websites, but the type and format of presentation of this information varied significantly among them. In fact, most websites included interactive web maps that allowed exploration by the public, but some retail websites still included this information using non-interactive tools (text or static maps). From the results obtained, it was concluded that most of these firms' websites included interactive store locators to provide information about their physical stores, but today some of them still use non-interactive (static) maps or text format to present this information.

\section{Conclusions}

The retail sector is continuously adapting to the changes brought about by globalization. The generalization in the use of computers and mobile devices has favored the adoption of new procedures and technologies. With millions of people connected to the Internet using electronic devices, retailers are investing a lot of resources in digital marketing, in order to establish a direct communication 
channel with clients using social media. Product information management is the process of managing information about products and the necessary data required to purchase, sell, and manage them. For this reason, interest in geomarketing strategies is gaining importance in retail firms, since they are used to determining the best marketing channels and strategies, promotional campaigns, etc., according to the spatial distribution and characteristics of customers. Companies are incorporating web mapping services (web GIS) in their websites to allow customers to find stores by interacting with maps.

Several previous studies have analyzed social media and e-commerce strategies used by retailers, but almost no attention has been paid to the use of online store locators to allow visitors to find nearby stores and shop locations. The double aim of this paper was to show the importance of store locator tools for digital marketing and to analyze the characteristics of online store locator services in specialty retailers' websites. To our knowledge, no paper has analyzed in detail the information provided by store locator search tools of large specialty retailers. With this purpose, the online store locator interactive tools of 63 specialty retailers' websites included in the report "Global Powers of Retailing 2015" were analyzed in detail from a double perspective: search options offered to the customer and information returned from the search.

The ideas and results studied in this research support previous theoretical studies that have showed the importance of digital marketing and geomarketing strategies in the retail sector. On the other hand, the results obtained provide empirical evidence about the inclusion of store locator services in large specialty retailers' websites. It was observed that most of these companies include online store locators using interactive maps on their websites in order to provide geographical information about the location and other important characteristics of the physical retail stores. However, there are still some large companies that use text or static maps to display this information. In addition to the quantitative data, the qualitative analysis carried out using word clouds allowed us to synthesize the information that specialty retailers provided in their websites about the location and services of their stores and to quickly visualize the different information given by retailers of different specialties. Given the advantages derived from the generalized use of mobile devices, such as smartphones, and the growing development of retail apps, it would be recommendable that any specialty retail company should use interactive maps on their websites to enhance their relationship with customers. This investigation could be extended to analyze small and medium-sized enterprises in this and other sectors of activity.

The limitations of the study were those related to the methodology used and the number of websites analyzed. The results of the investigation could be followed as indicators but a not generalization of the retail sector due to fact that there are thousands of retail firms around the world. As future work, it is planned to investigate other values of retailers' websites, according to website quality indexes proposed in the literature.

Author Contributions: G.W. and R.B. designed the investigation. R.B. and M.C.P.-M. collected and analyzed the data; G.W., M.C.P.-M. studied the implications of the results obtained; M.C.P.-M. and R.B. wrote the article; and all of the authors reviewed the manuscript.

Funding: This work was supported by the Catholic University of Murcia under contract PMAFI/18/14.

Conflicts of Interest: The authors declare no conflict of interest.

\section{References}

Albuquerque, Helena, Carlos Costa, and Filomena Martins. 2018. The use of Geographical Information Systems for Tourism Marketing purposes in Aveiro region (Portugal). Tourism Management Perspectives 26: 172-78. [CrossRef]

Baños, Raul, Gonzalo Wandosell, and María Concepción Parra. 2016. Web GIS to enhance relational capital: The case of general merchandise retailers. Journal of Knowledge Management 20: 578-93. [CrossRef]

Bao, Jie, Yu Zheng, David Wilkie, and Mohamed Mokbel. 2015. Recommendations in location-based social networks: A survey. GeoInformatica 19: 525-65. [CrossRef] 
Baxter, Roger, and Sheelagh Matear. 2004. Measuring intangible value in business-to-business buyer-seller relationships: An intellectual capital perspective. Industrial Marketing Management 33: 491-500. [CrossRef]

Berman, Barry. 2016. Planning and implementing effective mobile marketing programs. Business Horizons 59: 431-39. [CrossRef]

Busalim, Abdelsalam H., and Ab Razak CheHussin. 2016. Understanding social commerce: A systematic literature review and directions for further research. International Journal of Information Management 36: 1075-88. [CrossRef]

Cliquet, Gérard. 2006. Geomarketing: Methods and Strategies in Spatial Marketing. London: Wiley-ISTE.

Chacón-García, Jorge. 2017. Geomarketing techniques to locate retail companies in regulated markets. Australasian Marketing Journal 25: 185-93. [CrossRef]

Chambolle, Claire, and Sofia B. Villas-Boas. 2015. Buyer power through the differentiation of suppliers. International Journal of Industrial Organization 43: 56-65. [CrossRef]

De Beule, Matthias, Dirk Van den Poel, and Nico Van de Weghe. 2015. Assessing the principles of spatial competition between stores within a retail network. Applied Geography 62: 125-35. [CrossRef]

Deloitte Touche Tohmatsu Limited (DTTL). 2015. Global Powers of Retailing 2015. Available online: http:/ / www2.deloitte.com/content/dam/Deloitte/global/Documents/Consumer-Business/gx-cb-globalpowers-of-retailing.pdf (accessed on 28 January 2019).

ELSamen, Amjad Ahmad Abu, and Rund Ibrahim Hiyasat. 2017. Beyond the random location of shopping malls: A GIS perspective in Amman, Jordan. Journal of Retailing and Consumer Services 34: 30-37. [CrossRef]

Fernández, Pascual, Blas Pelegrín, Algirdas Lančinskas, and Julius Žilinskas. 2017. New heuristic algorithms for discrete competitive location problems with binary and partially binary customer behavior. Computers $\mathcal{E}$ Operations Research 79: 12-18. [CrossRef]

Fernández-Cavia, José, Cristòfol Rovira, Pablo Díaz-Luque, and Víctor Cavaller. 2014. Web Quality Index (WQI) for official tourist destination websites. Proposal for an assessment system. Tourism Management Perspectives 9: 5-13. [CrossRef]

Fernström, Lisa. 2005. A Marketing Perspective on Intellectual Capital. In Perspectives on Intellectual Capital. Edited by Bernard Marr. New York: Elsevier, pp. 82-95.

Fung, Simon Yu Kit, K. K. Raman, and Xindong (Kevin) Zhu. 2017. Does the PCAOB international inspection program improve audit quality for non-US-listed foreign clients? Journal of Accounting and Economics 64: 15-36. [CrossRef]

Gijsbrechts, Els, Katia Campo, and Tom Goossens. 2003. The impact of store flyers on store traffic and store sales: A geo-marketing approach. Journal of Retailing 79: 1-16. [CrossRef]

Hackl, Franz, Michael E. Kummer, Rudolf Winter-Ebmer, and Christine Zulehner. 2014. Market structure and market performance in e-commerce. European Economic Review 68: 199-218. [CrossRef]

Head, Keith, Ran Jing, and Deborah L. Swenson. 2014. From Beijing to Bentonville: Do multinational retailers link markets? Journal of Development Economics 110: 79-92. [CrossRef]

Hess, Ronald L., Ronald S. Rubin, and Lawrence A. West Jr. 2004. Geographic information systems as a marketing information system technology. Decision Support Systems 38: 197-212. [CrossRef]

Järvinen, Joel, and Heikki Karjaluoto. 2015. The use of Web analytics for digital marketing performance measurement. Industrial Marketing Management 50: 117-27. [CrossRef]

Kang, Ju-Young M., Jung Mee Mun, and Kim K.P. Johnson. 2015. In-store mobile usage: downloading and usage intention toward mobile location-based retail apps. Computers in Human Behavior 46: 210-17. [CrossRef]

Kim, Hyang-Sook. 2016. What drives you to check in on Facebook? Motivations, privacy concerns, and mobile phone involvement for location-based information sharing. Computers in Human Behavior 54: 397-406. [CrossRef]

Kounadi, Ourania, Bernd Resch, and Andreas Petutschnig. 2018. Privacy threats and protection recommendations for the use of geosocial network data in research. Social Sciences 7: 191. [CrossRef]

Lin, Heng-Chang, Yu-Cheng Chen, and Hsin-Hsi Lai. 2010. Integrating product information management (PIM) with internet-mediated transactions (IMTS). Journal of Convergence Information Technology 5: 99-108. [CrossRef]

Meroño-Cerdán, Angel L., and Pedro Soto-Acosta. 2007. External web content and its influence on organizational performance. European Journal of Information Systems 16: 66-80. [CrossRef] 
Palacios-Marqués, Daniel, Pedro Soto-Acosta, and José M. Merigó. 2015. Analyzing the effects of technological, organizational and competition factors on Web knowledge exchange in SMEs. Telematics and Informatics 32: 23-32. [CrossRef]

Palos-Sanchez, Pedro R., José Ramón Saura, Ana Reyes-Menendez, and Ivonne Vásquez. 2018. Users Acceptance of Location-Based Marketing Apps in Tourism Sector: An Exploratory Analysis. Journal of Spatial and Organizational Dynamics 6: 258-70.

Parise, Salvatore, Patricia J. Guinan, and Ron Kafka. 2016. Solving the crisis of immediacy: How digital technology can transform the customer experience. Business Horizons 59: 411-20. [CrossRef]

Pookulangara, Sanjukta, and Arlesa Shephard. 2013. Slow fashion movement: Understanding consumer perceptions-An exploratory study. Journal of Retailing and Consumer Services 20: 200-6. [CrossRef]

Pride, William M., O. C. Ferrell, Bryan Lukas, Sharon Schembri, and Outi Niininen. 2014. Marketing Principles. Melbourne: Cengage Learning Australia.

Priporas, Constantinos-Vasilios, Nikolaos Stylos, and Anestis K. Fotiadis. 2017. Generation Z consumers' expectations of interactions in smart retailing: A future agenda. Computers in Human Behavior 77: 374-81. [CrossRef]

Reigadinha, Tânia, Pedro Godinho, and Joana Dias. 2017. Portuguese food retailers-Exploring three classic theories of retail location. Journal of Retailing and Consumer Services 34: 102-16. [CrossRef]

Ríos-Martín, Miguel A., Pedro R. Palos-Sánchez, and Mariel Cáceres-Genao. 2017. Evaluation of the quality of tourism websites: empirical study based on IEW. Turismo e Sociedade 10: 1-32.

Roig-Tierno, Norat, Amparo Baviera-Puig, Juan Buitrago-Vera, and Francisco Mas-Verdu. 2013. The retail site location decision process using GIS and the analytical hierarchy process. Applied Geography 40: 191-98. [CrossRef]

Saboo, Alok R., V. Kumar, and Girish Ramani. 2016. Evaluating the impact of social media activities on human brand sales. International Journal of Research in Marketing 33: 524-41. [CrossRef]

Saura, José Ramón, Pedro Palos-Sánchez, and Luis Manuel Cerdá Suárez. 2017. Understanding the digital marketing environment with KPIs and web analytics. Future Internet 9: 76. [CrossRef]

Shankar, Venkatesh, Alladi Venkatesh, Charles Hofacker, and Prasad Naik. 2010. Mobile marketing in the retailing environment: Current insights and future research avenues. Journal of Interactive Marketing 24: 111-20. [CrossRef]

Shankar, Venkatesh. 2016. Mobile marketing: The way forward. Journal of Interactive Marketing 34: 1-2. [CrossRef]

Skarlatidou, Artemis, Tao Cheng, and Muki Haklay. 2013. Guidelines for trust interface design for public engagement Web GIS. International Journal of Geographical Information Science 27: 1668-87. [CrossRef]

Soto-Acosta, Pedro, and Juan-Gabriel Cegarra-Navarro. 2016. New ICTs for knowledge management in organizations. Journal of Knowledge Management 20: 417-22. [CrossRef]

Soto-Acosta, Pedro, Simona Popa, and Daniel Palacios-Marqués. 2016. E-business, organizational innovation and firm performance in manufacturing SMEs: An empirical study in Spain. Technological and Economic Development of Economy 22: 885-904. [CrossRef]

Ström, Roger, Martin Vendel, and John Bredican. 2014. Mobile marketing: A literature review on its value for consumers and retailers. Journal of Retailing and Consumer Services 21: 1001-12. [CrossRef]

Sydler, Renato, Stefan Haefliger, and Robert Pruksa. 2014. Measuring intellectual capital with financial figures: Can we predict firm profitability? European Management Journal 32: 244-59. [CrossRef]

Tagg, Stophen, Alan Stevenson, and Tiziano Vescovi. 2012. New Developments in Online Marketing. New York: Westburn Publishers Ltd., Routledge.

Tessem, Bjørnar, Solveig Bjørnestad, Weiqin Chen, and Lars Nyre. 2015. Word cloud visualisation of locative information. Journal of Location Based Services 9: 254-72. [CrossRef]

Tiago, Maria Teresa Pinheiro Melo Borges, and José Manuel Cristóvão Veríssimo. 2014. Digital marketing and social media: Why bother? Business Horizons 57: 703-8. [CrossRef]

Tsai, Juliana Y., T. S. Raghu, and Benjamin B.M. Shao. 2013. Information systems and technology sourcing strategies of e-retailers for value chain enablement. Journal of Operations Management 31: 345-62. [CrossRef]

Yang, Yang, Jingyin Tang, Hao Luo, and Rob Law. 2015. Hotel location evaluation: A combination of machine learning tools and web GIS. International Journal of Hospitality Management 47: 14-24. [CrossRef] 
Yi, Lee Wai, and Sharmila Jayasingam. 2012. Factors driving knowledge creation among private sector organizations: Empirical evidence from Malaysia. Journal of Organizational Knowledge Management 2012: 199983. [CrossRef]

Zavala-Romero, Olmo, Arsalan Ahmed, Eric P. Chassignet, Jorge Zavala-Hidalgo, Agustin Fernández Eguiarte, and Anke Meyer-Baese. 2014. An open source java web application to build self-contained web GIS sites. Environmental Modelling \& Software 62: 210-20. [CrossRef]

Zhao, Ling, Yaobin Lu, and Sumeet Gupta. 2014. Disclosure intention of location-related information in location-based social network services. International Journal of Electronic Commerce 16: 53-90. [CrossRef]

(c) (1)

(C) 2019 by the authors. Licensee MDPI, Basel, Switzerland. This article is an open access article distributed under the terms and conditions of the Creative Commons Attribution (CC BY) license (http:/ / creativecommons.org/licenses/by/4.0/). 